\title{
Pembelajaran Matematika Berbasis Etnomatematika Untuk Meningkatkan Minat Kelas 5 SDN 12 Langkanae Kota Palopo
}

\author{
Hasmawati $^{1}$, Suaedi ${ }^{2}$, Ma'rufi $^{3}$ \\ Universitas Cokroaminoto Palopo \\ Email: hasmawatisyahril@gmail.com¹, Suaedif@gmail.com², marufi@uncp.ac.id ${ }^{3}$
}

\begin{abstract}
ABSTRAK
Abstrak. Penelitian ini adalah salah satu penelitian eksperimen yang dilakukan di salah satu sekolah dasar yang ada di Kota Palopo yaitu Sekolah Dasar Negeri 12 Langkanae. Penelitian ini bertujuan untuk mendeskripsikan minat siswa kelas 5 SDN 12 Langkanae Kota Palopo sebelum dan setelah diajarkan pembelajaran matematika berbasis etnomatematika serta mengetahui apakah pembelajaran matematika berbasis etnomatematika dapat meningkatkan minat belajar siswa kelas 5 SDN 12 Langkanae Kota Palopo. Jenis desain penelitian ini adalah PraEksperimental designs dengan model one group pretets-posttes, sedangkan strategi yang digunakan adalah pembelajaran matematika berbasis etnomatematika yaitu permainan tradisional Sulawesi Selatan baguli dan ma 'dende. Adapun Instrument dari penelitian ini adalah lembar angket minat pretest dan posttest, untuk mengukur minat belajar siswa. Perlakuan yang diberikan pada penelitian ini pembelajaran berbasis etnomatematika. Hasil penelitian ditemukan bahwa: (1). Sebelum diajarkan pembelajaran berbasis etnomatematika terdapat 2 kategori yaitu kategori tinggi dan kategori cukup dimana jumah siswa yang berkategori tinggi dengan persentase $67 \%$, siswa dan kategori cukup persentase 33\%, setelah diajarkan pembelajaran berbasis etnomatematika kategori sangat tinggi persentase 48\%, siswa dengan kategori tinggi 52\% tidak ada berkategori cukup. (2). Terdapat pengaruh peningkatan minat setelah diajarkan pembelajaran berbasis etnomatematika $\mathrm{H} 1: \mu \mathrm{g} 1>0.299$ dengan skor gain sebesar 0,4250 .
\end{abstract}

Kata Kunci: Minat Matematika, Etnomatematika

\begin{abstract}
This research is an experimental research conducted in one of the elementary schools in Palopo City, namely the State Elementary School 12 Langkanae. This study aims to describe the interest of $5^{\text {th }}$ graders at SDN 12 Langkanae, Palopo City before and after ethnomathematics-based mathematics learning and to find out whether ethnomathematics-based mathematics learning can increase interest in 5th graders of SDN 12 Langkanae, Palopo City. The type of research design is pre-experimental design with one group pre-test-posttest model, while the strategy used is ethnomathematics-based mathematics learning, namely the traditional South Sulawesi games baguli and ma'dende. The instrument of this research is a pretest and posttest interest questionnaire, to measure students' interest in learning. The treatment given in this study was ethnomathematical-based learning. The results of the study found that: (1). Before being taught ethnomathematics-based learning there are 2 categories, namely high category and sufficient category where the number of students in the high category with a percentage of $67 \%$, students and the moderate category with a percentage of $33 \%$, after being taught ethnomathematics-based learning the very high category percentage is $48 \%$, students in the high category $52 \%$ not categorized enough. (2). There is an effect of increasing interest after being taught ethnomathematical-based learning H1: g1 $>0.299$ with a gain score of 0.4250
\end{abstract}

Kata Kunci: Mathematics Interset, Etnomathematics

\section{A. Pendahuluan}

Pendidikan adalah kegiatan saling berinteraksinya guru dan peserta didik. Pendidikan juga dapat diartikan adalah usaha kebudayaan yang bermaksud memberikan bimbingan dalam hidup tumbuhnya jiwa raga anak didik agar dalam garis-garis kodrat pribadinya serta pengaruh-pengaruh lingkungan, mendapat kemajuan hidup lahir batin (Ki Hadjar Dewantara, dalam Ki Suratman, 1987). Dalam Perundang-undangan dituliskan pada UU No. 20 Tahun 2003 pasal 3 Tentang Sistem Pendidikan Nasional, bahwa Tujuan pendidikan nasional adalah untuk mengembangkan potensi peserta didik agar menjadi manusia yang 
beriman dan bertakwa kepada Tuhan Yang Maha Esa, berakhlak mulia, sehat, berilmu, cakap, kreatif, mandiri, dan menjadi warga negara yang demokratis serta bertanggung jawab. Tujuan pendidikan ini akan tercapai bila semua pihak ikut mendukung kemajuan pendidikan baik pemerintah sebagai pemegang kebijakan, guru sebagai pendidik dan masyarakat sebagai tempat mereka berinteraksi secara sosial dan meniru.

Lingkungan sekolah dan guru memegang peranan sangat penting dalam pendidikan terutama proses belajar mengajar di sekolah. Pada siswa sekolah dasar (SD), guru tidak hanya di tuntut untuk mengajar dengan metode yang pasif seperti ceramah, dan mengajar sesuai buku teks yang ada, akan tetapi di harapkan agar siswa lebih banyak memperoleh pendidikan yang paling dasar dengan melibatkan mereka dalam bagaimana memperoleh pengetahuan dengan cara bermakna sehingga dapat menimbulkan pengetahuan yang kelak menjadi pengalaman dan pembelajaran berharga. Lingkungan keluarga dan lingkungan masyarakat dimana menjadi tempat mereka berinteraksi secara nyata dan meniru keadaan sosial di sekitar mereka juga tidak kalah pentingnya, karna karakter siswa dapat terbentuk dengan sendirinya di lingkungan ini. Oleh karna itu pentingnya memadukan pendidikan dengan memperhatikan keadaan lingkungan sekitar siswa.

Metode pembelajaran saat ini pada jenjang sekolah dasar pada umumnya masih mementigkan kan ketutansan materi dan tidak jarang mengabaikan hasil dan keterampilan siswa, khususnya Matematika. Pentingnya sebuah metode sangat berperan dalam sebuah keterlaksanaan sebuah pembelajaran. Metode pembelajaran adalah cara-cara menyajikan materi pelajaran yang dilakukan oleh pendidik agar terjadi proses pembelajaran pada diri siswa dalam upaya untuk mencapai tujuan (Sutikno, 2009).

Salah satu mata pelajaran siswa tingkat sekolah dasar yang dianggap sangat sulit adalah Matematika, diakibatkan pembelajaran matematika yang monoton hanya berdasarkan buku teks pelajaran yang tersaji di sekolah dan masih menjadi pegangan utama guru untuk mengajar. Kesulitan belajar juga dapat diartikan adalah keadaan dimana peserta didik tidak dapat belajar sebagaimana mestinya tentang logika mengenai bentuk, susunan, besaran, dan konsep-konsep yang berhubungan satu dengan yang lain (Nurjannah, dkk, 2019). Hal ini pula yang menjadi momok sehingga minat dan hasil belajar siswa ditingkat SD khususnya mata pelajaran matematika masih terbilang rendah. dan selain itu hakekat matematika menurut yaitu memiliki objek abstrak, bertumpu pada kesepakatan, dan pola berfikir yang deduktif. Dalam mata pelajaran matematika akan mempelajari kosep-konsep yang abstrak (Soejadi dalam Heruman, 2010). Melalui permainan anak tradisional khususnya permainan anak tradisional bugismakassar di harapkan dapat menjadikan matematika lebih nyata dan menyenangkan sehingga siswa dapat memiliki minat, motivasi, dan mampu mengembangkan kemampuan berpikir mereka dari sesuatu yang abstrak menjadi nyata, terutama dalam mengembangkan pemahaman mereka bernalar dalam pelajaran matematika merupakan salah satu mata pelajaran yang masih dianggap sukar untuk sebahagian besar siswa pada umumnya dan khususnya siswa sekolah dasar. Menurut Marufi, Ilyas,M., \& Winahyu, W. (2021), Asalkan siswa benar-benar memahami konsep matematika, bukan hanya retensi, dapat mendukung siswa untuk memecahkan masalah yang membutuhkan keterampilan berpikir tingkat tinggi. Hal ini dapat dikatakan bahwa mengaitkan budaya dan pembelajaran matematika atau yang lebih dikenal dengan istilah etnomatematika, akan menjadikan sesuatu yang baru dalam hal pembelajaran khususnya matematika, serta dapat menjadi salah satu solusi mengajar guru di tingkat sekolah dasar, karena pembelajaran etnomatematika yang terdapat dalam permainan tradisional dapat membantu siswa memahami konsep matematika.

Permainan tradisional anak di daerah Sulawesi Selatan khususnya daerah Kota Palopo sangat beragaman. Permainan tradisional suku bugis di Kota Palopo memiliki keunikan tersendiri tidak kalah dengan daerah lain di Nusantara. Dalam permainan tradisional selain mencintai tradisi kebudayaan melalui permainan juga mengandung berbagai aspek yaitu, 
Marekeng 'atau Mabbilang (berhitung), dan Maggambara` (mengambar suatu pola) yang semuanya ini merupakan dasar-dasar dalam pelajaran matematika. hal ini pula yang menjadi nilai tambah mengapa permainan tradisional sangat cocok untuk di jadikan bahan dalam mengajar khususnya matematika.

Berbagai penjelasan diatas mengenai permasalahan pemahaman kesulitan matematika ditingkat sekolah dasar serta bagaimana menciptakan metode yang menyenangkan, juga dapat ditemukan di pada siswa SDN 12 Langkanae Kota Palopo, sehingga peneliti mengambil judul "Pembelajaran Matematika Berbasis Etnomatematika untuk Meningkatkan Minat Kelas 5 SDN 12 Langkanae Kota Palopo".

Berdasarkan Latar belakang yang telah dikemukan di atas maka dirumuskan masalah utama dari Penelitian ini yaitu: 1). Bagaimanakah deskripsi minat belajar siswa kelas 5 SDN 12 Langkanae Kota Palopo sebelum dan setelah diajarkan pembelajaran matematika berbasis etnomatematika? dan 2). Apakah terdapat peningkatan minat belajar matematika siswa kelas 5 SDN 12 Langkanae setelah diterapkan pembelajaran matematika berbasis etnomatematika?

Sementara tujuan dari penelitian ini antara lain untuk mendeskripsikan minat siswa kelas 5 SDN 12 Langkanae Kota Palopo sebelum dan setelah diajarkan pembelajaran matematika berbasis etnomatematika, serta dapat mengetahui mengetahui peningkatan minat belajar matematika siswa kelas 5 SD Negeri 12 Langkanae Kota Palopo setelah diterapkan pembelajaran berbasis etnomatematika. Adapun manfaat dari penelitian ini adalah memberikan arah dan pedoman bagi guru-guru di tingkat SD untuk memadukan matematika dengan budaya lokal daerah setempat sebagai salah satu solusi mengajar yaitu bermain sambil belajar dan diharapkan penelitian ini dapat memperluas khasanah ilmu pengetahuan yang bermanfaat bagi semua pihak yang ada dalam bidang pendidikan

\section{B. Metodologi Penelitian}

Penelitian ini adalah penelitian eksperimen, jenis desain dalam penelitian ini adalah PraExperimental Designs. dengan model one group pretest-posttest. Adapun rancangan dari desain dapat dilihat pada Gambar dibawah ini.

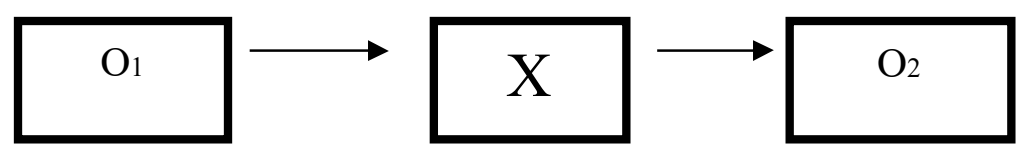

Gambar 1. Desain one group pretest-posttest.

Penelitian ini dilaksanakan di Sekolah Dasar Negeri 12 Langkanae kota Palopodan pelaksanaannya dimulai bulan mei 2021 sampai dengan bulan juli 2021 yang dimulai dari penyampaian surat izin dari Ketua Prodi Magister Pendidikan Matematika Universitas Cokroaminoto Palopo kepada kepala Sekolah Dasar Negeri 12 Langknae kota Palopo.

Penelitian ini sendiri dilaksanakan satu kelas yakni kelas 5A yang berjumlah 27 orang siswa. Teknik yang digunakan yang digunakan dalam pemilihan sampel adalah purposive sampling. Menurut Sugiyono (2017), purposive sampling yaitu teknik pengambilan sampel data yang didasarkan pada pertimbangan tertentu. Mengingat pada masa pandemi covid-19, siswa hanya belajar dari rumah dan tidak semua siswa memiliki gawai untuk belajar sehingga pembelajaran hanya berbasis daring dan luring. Kelas 5a juga menjadi pilihan peneliti dengan pertimbangan semua siswa kelas 5a memiliki fasilitas untuk menunjang pembelajaran daring. Instrument yang digunakan untuk mengumpulkan data dalam penelitian yaitu angket dan tes . Angket minat berjumlah 30 butir pertanyaan, untuk mengukur minat siswa. Soal yang diberikan pada saat pretest maupun posttest adalah soal yang sama yang membahas tentang minat siswa saat belajar matematika baik sebelum maupu sesudah menggunakan pembelajaran berbasis 
etnomatematika. kemudian diolah dengan analsisi data menggunakan SPSS, untuk uji analisis deskriptif dan analisis inferensial.

\section{Hasil Penelitian dan Pembahasan \\ 1. Hasil}

a. Hasil Analisis Deskriptif Angket minat siswa

Hasil awal pretest minat belajar matematika siswa sebelum diajarkan pembelajaran berbasis etnomaematika dapat disajikan seperti table dibawah ini.

Tabel 1. Kriteria Pretest Minat

\begin{tabular}{cllcc}
\hline NO & Skor Penilaian & Kategori & Frekuensi & Persentase (\%) \\
\hline 1 & $98-120$ & Sangat inggi & 0 & 0 \\
2 & $76-97$ & Tinggi & 18 & 67 \\
3 & $53-75$ & Cukup & 9 & 33 \\
4 & $30-52$ & Kurang & 0 & 0 \\
\hline
\end{tabular}

Sumber: Data Hasil Penelitian 2021

Setelah mengamati perhitungan tabel 5 diatas, pada pretest minat setelah dikonversi kedalam 4 kategori terdapat 2 kategori yaitu tinggi dan cukup, jumah siswa yang berkategori tinggi berjumlah 18 0rang dengan persentase 67\%, siswa dengan kategori cukup berjumlah 9 orang dengan persentase $33 \%$, dan tidak ada siswa yang berkategori kurang

Setelah diajarkan pembelajaran berbasis etnomatematika didapatkan hasil posttest hasil seperti tabel berikut.

Tabel 2. Kriteria(Posttest) Minat

\begin{tabular}{cllcc}
\hline No & Skor Penilaian & Kategori & Frekuensi & Persentase (\%) \\
\hline 1 & $98-120$ & sangat tinggi & 13 & 48 \\
2 & $76-97$ & Tinggi & 14 & 52 \\
3 & $53-75$ & Cukup & 0 & 0 \\
4 & $30-52$ & Kurang & 0 & 0 \\
\hline
\end{tabular}

Sumber: Data Hasil Penelitian 2021

Perhitungan tabel diatas meunujukkan hasik posttest minat, setelah dikonversi dalam emepat kategori terdapat 2 kategori yaitu sangat tinggi dan tinngi dimana jumah siswa yang berkategori sangat tinggi berjumlah 13 orang dengan persentase $48 \%$, siswa dengan kategori tinggi berjumlah 14 orang dengan persetase 52\%, siswa tidak ada siswa yang berkategori cukup dan kurang.

Hasil analisis statistik deskriptif peningkatan minat dari pre test ke posttest pada tabel 1 dan tabel 2, setelah diajarkan pembelajaran berbasis etnomatematika kemudian diuji peningkatan rata-rata perolehan skor berdasarkan uji $\mathrm{N}$-Gain ternormalisasi.

Hasil uji $\mathrm{N}$-Gain ternormalisasi terdapat peningkatan setelah diajarkan matematika berbasis etnomatematika, dapat dilihat pada tabel dibawah berikut ini,

Tabel 3. Uji $\mathrm{N}$-Gain ternormalisasi Pre test-posttest minat.

\begin{tabular}{llcc}
\hline Koefisien Normalisasi Gain & Klasifikasi & Frekuensi & Persentase (\%) \\
\hline $\mathrm{g} \geq 0,7$ & Tinggi & 2 & 8 \\
$0,3 \leq \mathrm{g} \leq 0,7$ & Sedang & 19 & 70 \\
$\mathrm{~g}<0,3$ & Rendah & 6 & 22 \\
\hline
\end{tabular}

Sumber: Data Hasil Penelitian 2021.

Setelah melihat tabel uji $\mathrm{N}$-Gain ternormalisasi tabel diatas di simpulkan bahwa terjadi peningkatan minat belajar siswa setelah diajarkan pembelajaran berbasis etnomatematika angka 
rata rata $N$-Gain 0,4250 dengan kategori sedang. Sedangkan untuk hasil pre test-posttest minat dari nilai rata rata 77 menjadi 97.

b. Hasil uji Analisis Data Statistik Inferensial

1. Uji Normalitas N-Gain Minat belajar matematika

Berdasarkan hasil output uji normalitas $N$-Gain minat dengan menggunakan uji Lilliefors (Kolmogorov-Smirnov)

Tabel 4. Uji Normalitas $N$-Gain minat

\begin{tabular}{|c|c|c|c|c|c|c|}
\hline \multirow[b]{2}{*}{$\begin{array}{l}\text { Uji Normalitas N-Gain } \\
\text { Minat }\end{array}$} & \multicolumn{3}{|c|}{ Kolmogorov-Smirnov ${ }^{a}$} & \multicolumn{3}{|c|}{ Shapiro-Wilk } \\
\hline & $\begin{array}{c}\text { Statistic } \\
0.106\end{array}$ & $\begin{array}{l}\mathrm{df} \\
27\end{array}$ & $\begin{array}{c}\text { Sig. } \\
0.200^{*}\end{array}$ & $\begin{array}{c}\text { Statistic } \\
0.958\end{array}$ & $\begin{array}{l}\mathrm{df} \\
27\end{array}$ & $\begin{array}{c}\text { Sig. } \\
0.329\end{array}$ \\
\hline
\end{tabular}

Sumber: Data Hasil Penelitian 2021

Tabel diatas menunjukkan nilai signifikansi pada kolom signifikansi 0,200 Karena nilai signifikansi lebih dari 0,05 dimana 0,200 > 0,05 maka dapat dikatakan bahwa Minat belajar matematika setelah diajarkan pembelajaran berbasis etnomatematika berdistribusi normal, maka $\mathrm{H}_{\mathrm{o}}$ diterima. Maka minat belajar berdistribusi normal.

c. Hasil Uji Hipotesis

Untuk keperluan pengujian hipotesis maka digunakan Uji one Sample T Test dengan dasar pertimbangan pengambilan keputusan yaitu jika:

1). Nilai signifikansi (2-tailed) $<0,05$, maka $\mathrm{H}_{0}$ ditolak dan $\mathrm{H}_{1}$ di terima

2). Nilai signifikansi (2-tailed) $>0,05$, maka di tolak $\mathrm{H}_{1}$ dan $\mathrm{H}_{0}$ di terima

Setelah melalakukan uji statistik inferensial yaitu Uji one Sample T Test Terdapat peningkatan minat, hal ini dapat dilihat pada tabel Uji one Sample T Test dibawah ini.

Tabel 5. Uji one-sample Test.

\begin{tabular}{|c|c|c|c|c|c|}
\hline \multicolumn{6}{|c|}{ Test Value $=.299$} \\
\hline & & & Mean & $95 \%$ & of the Difference \\
\hline $\mathrm{T}$ & Df & Sig. (2-tailed) & Difference & Lower & Upper \\
\hline 2.558 & 26 & .017 & .1259481 & .024725 & .227171 \\
\hline
\end{tabular}

Sumber: Data Hasil Penelitian 2021

Pada tabel diatas uji peningkatan minat belajar matematika setelah diajar dengan pembelajaran berbasis Etnomatematika menggunakan uji one sample T test, menunjukkan nilai (2-tailed) adalah 0,017 . Hal ini menunjukkan bahwa $\mathrm{H}_{0}$ ditolak dan $\mathrm{H}_{1}$ di terima yaitu gain ternormalisasi minat belajar setelah diajarkan pembelajaran berbasis etnomatematika secara signifikan lebih besar dari 0,299 dan berkategori sedang. sehingga dapat dikatakan terdapat peningkatan minat belajar siswa setelah diajarkan pembelajaran matematika berbasis etnomatematika.

\section{Pembahasan}

Minat dalam kamus besar Bahasa Indonesia (online), diartikan dengan kecenderungan hati yang tinggi terhadap sesuatu, gairah, dan keinginan. Serupa dengan Poerwanto (2010), memaknai minat sebagai kecenderungan hati yang tinggi terhadap sesuatu. Djamarah (2008), mengatakan minat adalah suatu rasa lebih suka dan rasa ketrikatan pada suatu hal atau aktivitas tanpa ada yang menyuruh. Rusmiati (2017), mengartikan minat sebagai karekteristik kemampuan untuk memusatkan perhatian dengan penuh kemauan pada suatu keadaan yang tergantung bakat dan lingkungan. Dalam kata lain bahwa minat merupakan karakteristik 
seseorang berupa kekuatan khusus yang terdapat didalam diri seseorang, yang kecenderungannya atau keinginannya sangat tinggi atau sangat suka terhadap sesuatu.

Minat mempunyai peranan yang sangat penting dalam perkembangan belajar siswa. Siswa yang menaruh minat pada suatu bidang tertentu, maka akan berusaha lebih keras dalam menekuni bidang tersebut dibanding siswa yang tidak menaruh minta. Menurut Slameto (2003), minat merupakan suatu rasa lebih suka dan rasa keterikatan pada suatu hal atau aktivitas, tanpa ada yang menyuruh. Dengan kata lain, minat merupakan suatu rasa lebih senang dalam diri seseorang dalam memberikan perhatian yang lebih besar terhadap objek tertentu. Sedangkan menurut Nasution (2008), bahwa ketekunan belajar ini bertalian dengan sikap dan minat terhadap pelajaran. Bila suatu pelajaran tidak menarik minat seseorang karena sesuatu hal, maka ia segera menyampingkannya jika menemukan kesulitan. Sebaliknya, jika suatu tugas menarik karena memberikan hasil yang menggembirakan, ia cenderung untuk memberikan waktu yang lebih banyak untuk tugas.

Hasil Obsevasi Peningkatan Minat pada penelitian ini dapat dilihat pada beberapa Indikator minat yang menunjukkan ada nya perubahan dari minat belajar matematika siswa sebelum dan setelah diajarkan pembelajaran matematika berbasis etnomatematika, adapun indikator minat yang dimaksud indikator minat belajar matematika yang terdiri dari:

a. Perasaan senang mengikuti pembelajaran

b. Perhatian saat mengikuti pembelajaran, berdiskusi bersama guru dan teman-teman sekelasnya tentang pembelajaran matematika .

c. Ketertarikan dimana siswa ingin tahu tentang yang berkaitan dengan pelajaran matematika.

d. Keterlibatan siswa dalam menyelesaikan tugas, kesadaran tentang belajar kembali dirumah dan kegiatan sebelum dan sesudah pembelajaran matematika.

Beberapa indikator diatas menjadi tolak ukur untuk menggali sejauh mana minat siswa belajar matematika. Indikator-indikator dihubungkan dengan materi belajar matematika menggunakan permainan tradisional, atau yang saat ini disebut dengan istilah etnomatematika, dimana pembelajaran matematika dikaitkan dengan budaya agar dapat menjadi hal yang lebih menarik. Permainan tradisional pada penelitian ini adalah permainan yang sengaja dipilih oleh peneliti yang berkaitan langsung dengan pembelajaran matematika di kelas 5 Tingkat Sekolah Dasar yaitu materi kecepatan yang di ajar melalui permainan baguli dan materi jaring-jaring kubus yang diajarkan melalui permainan ma'dende.Setelah melakukan pembelajaran matematika berbasis etnomatematika yang diajarkan melalui pembelajaran dengan sistem blended learning (daring dan luring), didapatkan beberapa hal yaitu: 1). Siswa menjadi kembali mengingat permainan tradisional yang sering mereka mainkan.2). Siswa secara mandiri aktif bermain sambil melakukan kegiatan-kegiatan matematika seperti menggambar pola, melakukan pengukuran satuan panjang menggunakan alat ukur berupa penggaris dan mistar, serta siswa secara mandiri melakukan perhitungan dengan bantuan rumus matematika yang telah dipelajari sebelumnya.3). Saat diberi tugas membuat video pembelajaran siswa sangat bersemangat untuk menampilkan yang terbaik.

dengan adanya antusias siswa seperti yang dapatkan digambarkan dalam observasi selama penelitian maka dapat dikatakan bahwa permainan tradisional meningkatkan minat belajar matematika siswa.

Melalui perhitungan statistik deskriptif dapat terihat adanya peningkatan minat meskipun masih tergolong sangat sedang, hal ini dapat dilihat dari perbedaan rata-rata hasil pretest dan hasil posttest. dimana hasil preetest sebelum diajarkan pembelajaran matematika berbasis etnomatematika nilai rata-rata pretest siswa adalah 77 dan setelah dilakukan pembelajaran matematika berbasis etnomatematika diadapatkan nilai rata-rata posttest meningkat menjadi 97, peningkatan hasil rata-rata pre test-posttest serta didukung oleh uji Ngain Pre test- Posttest minat dengan skor 0,4250. 


\section{Kesimpulan dan Saran}

\section{Kesimpulan}

1. Sebelum diajarkan pembelajaran berbasis etnomatematika terdapat 2 kategori yaitu kategori tinggi dengan persentase $67 \%$, dan cukup persentase $33 \%$, setelah diajarkan pembelajaran berbasis etnomatematika kategori sangat tinggi persentase $48 \%$, siswa dengan kategori tinggi 52\% tidak ada berkategori cukup.

2. Dengan Kegiatan belajar sambil bermain permainan tradisional siswa lebih aktif dalam berhitung, mengukur jarak, membuat pola. hal ini juga didukung melalui uji $\mathrm{N}$-gain peningkatan rata-rata Pretest dan Posttet kategori sedang dengan skor $\mathrm{N}$-gain sbesar 0,4250 .

\section{Saran}

Pada Penelitian ini, penulis masih menyadari terdapat banyak kekurangan oleh karna itu penulis memberikan beberapa saran diantaranya:

1. Bagi para peneliti sejenis selanjutnya, disarankan agar dalam melakukan penelitian matematika berbasis etnomatematika yang menghubungkan pembelajaran matematika dengan budaya- budaya lokal.

2. Penelitian yang akan datang berbasis etnomatematika dapat lebih mengaitkan pembelajaran matematika tidaknya ada pada permainan tradisional bugis-Makassar, tetapi pada berbagai jenis budaya misalnya pola perilaku masyarakat yang mempercayai angka sakral tertentu, garis dan bidang pada huruf lontara.

3. Penelitian etnomatematika hendaknya dapat dilakukan di dua sekolah dasar yang berbeda tentunya dengan asumsi, bahwa kedua sekolah tersebut mempunyai karakteristik yang tidak jauh berbeda dalam satu daerah.

\section{DAFTAR PUSTAKA}

Abadi, A. P. (2020). Minat Belajar Siswa Dalam Pembelajaran Matematika. Prosiding Seminar Nasional Matematika dan Pendidikan Matematika Sesiomadika. Universitas Singaperbangsa Karawang..Hal 1502-1508.

Aprilia, E. D., Trapsilasiwi, D., \& Setiawan, T. B. (2019). Etnomatematika pada Permainan Tradisional Engklek Beserta Alatnya sebagai Bahan Ajar. Kadikma, 10(1),Hal 85-94.

Febriyanti, C., Prasetya, R., \& Irawan, A. (2018). Etnomatematika Pada Permainan Tradisional Engklek Dan Gasing Khas Kebudayaan Sunda. Barekeng: Jurnal Ilmu Matematika Dan Terapan, 12(1), 1-6.

Heriyati, H. (2017). Pengaruh Minat dan Motivasi Belajar Terhadap Prestasi Belajar MatematiSka. Formatif: Jurnal Ilmiah Pendidikan MIPA, 7(1).

Ilyas, M.(2015). Metodelogi Penelitian Pendidikan Matematika. Bandung.Pustaka Ramadhan.362 hal.

Irawan, A., \& Kencanawaty, G. (2017). Implementasi pembelajaran matematika realistik berbasis etnomatematika. Journal of Medives: Journal of Mathematics Education IKIP Veteran Semarang, 1(2), 74-81.

Kencanawaty, G., \& Irawan, A. (2017). Penerapan etnomatematika dalam pembelajaran matematika di sekolah berbasis budaya. EKUIVALEN-Pendidikan Matematika, 27(2). 
Marufi, M., Ilyas, M., \& Winahyu, W. (2021). an Implementation of Ethno-STEM to Enhance Conceptual Understanding. Al-Jabar: Jurnal Pendidikan Matematika, 12(1), 35-44 